\title{
(息)
}

Citation:

Singh, D (2014) Corruption and clientelism in the lower levels of the Afghan police. Conflict, Security and Development, 14 (5). 621 - 650. ISSN 1467-8802 DOI: https://doi.org/10.1080/14678802.2014.963391

Link to Leeds Beckett Repository record:

https://eprints.leedsbeckett.ac.uk/id/eprint/2647/

Document Version:

Article (Accepted Version)

The aim of the Leeds Beckett Repository is to provide open access to our research, as required by funder policies and permitted by publishers and copyright law.

The Leeds Beckett repository holds a wide range of publications, each of which has been checked for copyright and the relevant embargo period has been applied by the Research Services team.

We operate on a standard take-down policy. If you are the author or publisher of an output and you would like it removed from the repository, please contact us and we will investigate on a case-by-case basis.

Each thesis in the repository has been cleared where necessary by the author for third party copyright. If you would like a thesis to be removed from the repository or believe there is an issue with copyright, please contact us on openaccess@leedsbeckett.ac.uk and we will investigate on a case-by-case basis. 


\section{Corruption and clientelism in the lower levels of the Afghan police}

Danny Singh

Some scholars argue that the Afghan police are regularly engaged in bribery and drugrelated corruption. Prevalent corruption in the Afghan police has demonstrably resulted in greater support for the Taliban which is a threat to security. This suggests that a robust anticorruption strategy is needed to restore legitimacy in the Afghan state and police and to counter the insurgency. This article initially provides a discussion of police corruption in Afghanistan that reveals four interrelated explanations: (1) structural causes of corruption, patronage and nepotism, (2) low pay, (3) state capture, and (4) ethnic favouritism. The research methodology included 70 semi-structured interviews with elites conducted by the author in Kabul during May-June 2010 and 100 surveys conducted with patrolmen and lieutenants in various Afghan provinces during January-March 2012. The article finds that it can prove counterproductive to post poorly paid policemen in distant provinces in order to challenge patronage relations as it tends to exacerbate survival-based corruption. Moreover, improved pay reform could help reduce survival-based corruption in the Afghan police but systemic corruption, clientelism and state capture will remain if it is not implemented alongside other wider structural initiatives.

\section{Introduction}

In Afghanistan, administrative corruption, state capture, systemic and political corruption, patronage, cronyism, bidding for Chief of Police $(\mathrm{CoP})$ appointments and drug-related corruption has hindered effective law enforcement. This is due to the fact that institutions and anti-corruption units have been infiltrated by the government to serve criminal interests. Those criminal interests are often linked to the drug trade. As a number of experts have 
observed, many elements of Afghan government structures serve individual patrons and not the wider public interest. ${ }^{1}$ For instance, appointments of senior officials, such as police chiefs and provincial governors, are based on bidding wars: positions regularly sell for hundreds of thousands of United States (US) dollars and these positions cost even more in high drug producing areas. ${ }^{2}$ This has distorted both the provision of security and the rule of law.

The rule of law is perverted by the Afghan police to serve all manner of criminal activities, such as: drug trafficking (and preserving the interests of criminal groups involved in trafficking), land theft, real estate swindling, tax and customs evasion, the operation of illegal security forces and illegal monopolies on markets with legal goods, and so forth. The Afghan National Police (ANP) and Afghan government are perceived as highly corrupt in the eyes of ordinary Afghans. This has led to public discontent toward an illegitimate government and police force that has arguably remobilised support for the Taliban. As a consequence, the security situation has further deteriorated. Therefore, a robust anticorruption strategy for the Afghan police force is required due to the fact that — as is held to be central to the proper functioning of a liberal state - the police and judges are pivotal law enforcement actors.

This article examines the features of corruption and clientelism in the Afghan police and assesses the effectiveness of the anti-corruption strategies implemented to date. In the first section, the research methodology is outlined and this is followed by an overview of the different forms corruption takes and the perceptions of corruption among ordinary Afghans. This allows for a consideration of four prominent causes of corruption in the Afghan police. Subsequently, the following two sections discuss internal Ministry of Interior (MoI) anticorruption strategies, pay reform, recruitment and stationing in the ANP. This provides the basis for an analysis of the findings from the original research conducted by the author, 
consisting of interviews and surveys. It provides insights with respect to the respondents' perceptions on pay and living costs, corruption, clientelism and anti-corruption strategies.

The article finds that pay reform alone will fail to combat systemic corruption, clientelism and state capture. Moreover, care needs to be taken when randomly assigning low- paid policemen, particularly sole breadwinners, in distant provinces to undermine the phenomenon of policemen remaining loyal to local power-brokers. This serves the purpose of reducing patronage corruption on the one hand, however, economic-incentive-based forms of corruption may intensify on the other. Those officers posted away to other provinces find circumstances very tough — prompting reliance on illicit activities — which undermines the effectiveness of anti-corruption strategies, namely pay reform and random assignment. This will be explored in the analysis.

\section{Research methodology}

Existing primary case studies have involved research conducted with the ANP but usually at the higher levels. ${ }^{3}$ Hence, there is a gap in the literature with only limited research conducted thus far with lower ranks of the Afghan police, which make up the majority of the ANP. In order to contribute to this area with original empirical data, initially 70 semi-structured interviews were conducted with elites in Kabul during May-June 2010 concerning corruption and clientelism in the Afghan security and judicial sectors. This was followed by surveys conducted in January-March 2012 with lower levels of the uniform police, covering the main issues of corruption and clientelism.

Due to deteriorating security conditions in Afghanistan the researcher decided to conduct surveys with the assistance of a known local Afghan company. One hundred surveys were conducted by the researcher and Quest Companies, initially in Kabul. However, the research team had to relocate to 14 other nearby provinces due to the security crisis in the capital 
during late February-March $2012 .{ }^{4}$ Consequently, the research team completed the surveys in the local researchers' home provinces, which were mainly Logar and Laghman, in which there were better logistics. This means that the findings are not generalisable for the entirety of Afghanistan due to the surveys being small scale. It must therefore be stressed that the figures presented in the findings are not statistically significant. Yet, the purpose of these surveys is to bring out low-ranked policemen's perceptions on living standards, corruption and anti-corruption qualitatively.

Of the 100 surveys, 76 were conducted with patrolmen, followed by 16 with first lieutenants and eight with second lieutenants. Sixteen surveys were conducted in Kabul, 26 in Logar, 14 in Laghman, six in Nangarhar, six in Kunduz, six in Kapisa, four in Paktia, four in Panjshir, four in Takhar, four in Khost, two in Jowzjan, two in Kunar, two in Bamiyan, two in Maidan Wardak and two in Parwan. The key variables (determinants of corruption) surveyed were: family size, owned/rented house, sole/multiple breadwinners, living costs, expenses and home/away province. These have an impact on economic necessity and 'survival-based corruption'.

\section{Corruption in the Afghan National Police}

Prior to any analysis of anti-corruption strategies, it is important to provide a broad overview of corruption relating to the ANP. It must be stressed that the Afghan police forces consist of several branches and structures, such as the Afghan Uniform Police (AUP), Afghan Border Police (ABP), the Counter Narcotics Police of Afghanistan (CNPA) and Afghan National Civil Order. ${ }^{5}$ This paper primarily focuses on corruption within the lower levels of the uniformed police. The forms and perceptions of corruption are considered below. 


\section{Forms of corruption}

Police corruption concerns the misconduct of police officers and patrolmen. Prominent examples of this are: accepting bribes and extorting illegal tolls; manipulating laws, duties and rules; breaching human rights; and interfering with investigations, arrests and the justice system to obtain financial or personal gain. Bribery and extortion are two main forms of police corruption that provide officers with opportunities to make additional money to supplement poor wages. Police officers may demand extortive payments from citizens, such as false traffic fines in Pakistan, or else threaten to arrest citizens if a falsified fee is not paid. ${ }^{6}$

Similarly in Afghanistan, the ANP has developed a reputation of engaging in bribery and toll extortion. In many cases at the provincial level, the traffic police request payments to allow vehicles to pass. If these are not paid, drivers face being charged for bogus violationsthe proceeds from which are then paid up the chain of command to the CoP. In Kandahar, senior police have been charging 20,000 Afghanistan Afghani (AFN) (an estimated US\$400 at the time) for every passing vehicle, and failure to pay leads to seizure of the vehicle. ${ }^{7}$ Moreover, police commanders collect wages of 'ghost' policemen by overstating the numbers working under them. ${ }^{8}$ Often, the Ministry of Finance representative who 'was supposed to supervise the CoP' would have involvement in such corruption. ${ }^{9}$

There are certain factors motivating police corruption such as the possible illicit rewards to be won by engaging in poppy trafficking. This usually occurs at the provincial level with local power brokers and the local government. ${ }^{10}$ The police also manipulate poppy eradication schemes by extorting bribes from farmers. The Afghan security forces are corrupt in many more ways than simply taxing cultivators of the poppy crop or smuggling opium. Other corrupt practices include roadside extortion, equipment and uniform abuse and paying off bosses to retain posts in profitable areas for extortive practices. ${ }^{11}$ In addition, there is a sense that prosecution and justice are commodities for sale. ${ }^{12}$ For instance, the United States 
Institute of Peace (USIP) Rule of Law Advisor argued that drug smugglers are able to bribe or intimidate police and judges to drop their charges. ${ }^{13}$ All the ANP, particularly the ABP and the CNPA, are overwhelmed with drug-related corruption. ${ }^{14}$ Criminals or drug-lords may often bribe senior police officers or border police in exchange for cash incentives in the Afghan narcotics industry and local power brokers are engaged in the drug-related protection industry.

The police are also prey to corrupt senior actors that can breed corruption in the lower ranks, who have low literacy rates of $14-15$ per cent. ${ }^{15}$ The Head of Transitional Justice for the United Nations Assistance Mission in Afghanistan (UNAMA) similarly argued that 'corruption is widespread all over institutions' and 'this is more evident in the security forces' ${ }^{16}$ However, it should be acknowledged that there are differences between the police and army.

Despite the huge resources invested by international donors, patronage has flourished. Individuals and groups compete for favours from patrons who distribute state resources and jobs and this can disrupt police reform and clear policy-making. ${ }^{17}$ Therefore, it is also important to note that a principal driver of corruption among the Afghan police is ethnic favouritism. This has an important influence on both internal structures and promotions within the police as well as police relations with local communities and hence their perceived legitimacy. There are clear ethnic patterns when studying CoP appointments from different Ministers of Interior: for instance, Tajiks and Uzbeks were heavily over-represented in 2002 due to the Northern Alliance reaping the benefits from the defeated Taliban and Tajiks are still over-represented. ${ }^{18}$ 


\section{Perceptions of corruption}

There are many explanations why Afghan policemen engage in corrupt practices. As a staff member of the Ministry of Agriculture, Irrigation and Livestock (MAIL) explained:

they get peanuts that hardly caters for their food so they have to do other things and some may join the insurgency, part-time, or other clientelistic networks. The police earn around 70 Afghanis a day (an estimated US\$1.45 at the time) and most are illiterate with minimal training despite international donors. ${ }^{19}$

In the ANP, salaries are low at US\$70 monthly, which is insufficient to cater for an Afghan family and often leads to stealing and survival-based corruption.

Afghans stress that corruption is prevalent throughout the ANP which is revealed in corruption perception reports. In an Afghan nationwide survey conducted for the UNDP, 27 per cent of respondents in Kabul claimed that many police personnel routinely abuse their authority and 21 per cent thought the same nationwide. ${ }^{20}$ Almost two thirds of Afghans (65 per cent) believed that many police officers use office equipment for personal use and 52 per cent stressed that the ANP abuse their authority. It was also emphasised by 42 per cent of the respondents that bribes and gifts are commonly given when communicating with the ANP. Almost half (48 per cent) stated that shopkeepers are regularly forced to pay a protection fee to policemen. ${ }^{21}$ However, it is crucial to stress that public perceptions of police corruption are complex and there are many entities within the Afghan police. Therefore such opinions are based on the ANP overall but principally concern everyday street police as most Afghans interact with them on a daily basis.

Another nationwide Afghan civil society corruption perception report conducted by Integrity Watch Afghanistan (IWA) surveyed the perceptions of 1,258 Afghan respondents on corruption. Of these respondents, 70 per cent believed that corruption is the most prevalent 
problem across Afghanistan insofar as it undermines the services provided by the security, justice and public sectors. ${ }^{22}$ The report also argues that the Afghan police is the most publically hated and most corrupt institution in the country that regularly extorts bribes from everyday civilians. ${ }^{23}$ Corruption can be seen to have threatened state-building and statesociety relations, empowered the insurgency, increased social inequality, hampered the rule of law and access to basic public services and led to human rights violations on a daily basis. ${ }^{24}$ All of these factors constrain economic development and affect the poor disproportionately: poorer households are forced to pay a higher slice of their income as bribes for basic services on a daily basis. ${ }^{25}$

Such perceptions of high levels of corruption in the Afghan government and police have led to increased support for the Taliban. In the IWA survey, 60 per cent of respondents claimed that the Karzai administration has been the most corrupt over the last 20 years with the MoI and the courts being the most corrupt institutions. ${ }^{26}$ According to the Head of Access to Justice for The Asia Foundation, the Karzai-led government is arguably one of the most corrupt regimes in Afghanistan's history and has been even worse than the Taliban when they were in power-a striking observation given that the latter were far more violent and restrictive of civil liberties and human rights than the current Government of Afghanistan. ${ }^{27}$ In the IWA survey, 50 per cent of respondents stressed that corruption contributes to the growth of the Taliban and a third of the respondents claimed that the Taliban are fighting against corruption in the Afghan government. ${ }^{28}$ Engelhardt argues that the police are fuelled by corruption and prefer to desert rather than fight unlike the Taliban. ${ }^{29}$

Many Afghans, particularly truckers, that are frustrated by roadside extortion and increased taxes have called for a return of the Taliban regime to bring an end to police corruption. ${ }^{30}$ Mullah Omar, head of the Taliban, stated that the Afghan police are immoral, irreligious, drug addicts and are rejected from their families and, therefore, are unable to 
protect the dignity, honour and property of the Afghan people. ${ }^{31}$ The Taliban even promulgated their own Code of Conduct in 2006, in part to underline the high levels of corruption in the Afghan police. As a consequence, local Afghans face the dilemma of whom to side with and continually have to navigate the complex web of local power actors to ensure their own survival and protection. ${ }^{32}$ Dissatisfaction with the Afghan National Security Forces (ANSF) and the Taliban has also led to the emergence of local anti-Taliban uprisings from locally revived or formed armed militias. These groups have been legitimised under the façade of the Afghan Local Police (ALP) to fight the insurgency in remote insecure areas. ${ }^{33}$

Farmers that cultivate the illicit poppy-crop are taxed by the Taliban, local power brokers, police forces, eradication forces and the ALP to preserve lucrative livelihoods for poppy cultivation because the Afghan government is not functional in these insecure areas. ${ }^{34}$ UNDP's survey also reveals that public perceptions of police engaging in the drug trade and crime are high in Kabul (54 per cent drugs; 44 per cent crime) and Paktika (61 per cent drugs; 70 per cent crime). ${ }^{35}$

\section{Exploring the causes of corruption in the Afghan police}

The previous section looked at the broad manifestations of corruption in the Afghan police. It is now necessary to explore the prominent causes of the phenomenon. This section seeks to draw out four prominent causes of corruption as identified through the original research conducted as part of this study.

\section{Structural causes of corruption, patronage and nepotism}

Patrons that own state resources often favour family, friends, tribes and political supporters for appointments, financial gain or lucrative opportunities ${ }^{36}$ Moreover, systemic corruption is prevalent within the MoI and individuals purchase or rent a post by paying a lump sum and/or 
sending a monthly stipend of bribes extorted up the chain of command to their superior or recruiter to maintain their post. This is common in lucrative drug areas. It is also linked to non-meritocratic recruitment and prevalent patron-client relations.

The Director of the American Institute of Afghanistan claimed that governorships, senior ministerial and police chief posts are provided by political elites on the basis of loyalty and bidding wars rather than meritocracy. ${ }^{37}$ Moreover, President Hamid Karzai's cabinet has been involved in the narcotics trade. A worker for MAIL claimed that many provincial governors bid or have nepotistic kinship ties to control areas. ${ }^{38}$ An example identified by the Head of Access to Justice Programme for The Asia Foundation is of the late Ahmad Wali Karzai, an internationally renowned drug trafficker, appointed as the governor of Kandahar by his halfbrother, President Karzai. ${ }^{39}$ Such forms of corruption are systemic and engrained in the majority of Afghan state institutions.

Furthermore, there are cultural connotations concerning bribery and gift-giving. These may be deemed as forms of corruption in the West but not in some Asian and African societies. ${ }^{40}$ In Afghanistan, daily bribery and providing a small gift is a frequent mode of contract to speed-up a transaction or basic service between the bribe payer and bribe takerusually a civil servant, policeman or judge. ${ }^{41}$ For instance, a Legal Consultant of the Justice Sector Support Programme (JSSP) claimed that he had to pay money to get his drivers' licence issued so that he could take up his new post to earn money to cater for his family. ${ }^{42}$ Similarly, the Project Co-ordinator of the Centre for Policy and Human Development (CPHD) argued that 'it is an unbelievable task to be able to get your passport without paying someone a bribe' because of the prevalence of so-called 'administrative corruption'. ${ }^{43}$ Corruption does have cultural connotations and is thus a social construction. However, the main argument is that corruption, whether perceived as systemic or cultural, is engrained in both Afghan state structures and society as part of everyday interactions. 


\section{Economic necessity}

Corruption is caused by the lack of economic provision. Wages are inadequate to cover costs of living, which leads to the police demanding bribes and extortion as a survival strategy. This is particularly evident with low-ranked policemen. When taking this explanation into account, corruption and economic need are interrelated. A Legal Consultant of JSSP argued that houses for rent in Afghanistan are 'not less than US\$400' and the wages of policemen and prosecutors are under half of this amount. As a consequence, 'when a policeman or prosecutor does not have enough money to pay the rent of his house; he will take bribes'. ${ }^{44}$ Increasing the wages of the police may reduce corruption if one surmises that corrupt behaviour is induced by low salaries: bribe money would be reduced if incomes rise.

Afghan legal experts argue that pay needs to be effectively reformed in the Afghan police and judicial system in order to reduce corruption and bribery. ${ }^{45}$ In addition, anticorruption and civil society senior personnel claimed that paying higher salaries to the security forces can guarantee economic security for their families, enhance loyalty to the state and counter both corruption and the insurgency. ${ }^{46}$ Hence, the provision of adequate wages, a secure living environment and decreasing incentives for engaging in corruption are crucial to counter corruption in the police.

\section{State capture}

Parts of the state that include the government, security and justice sectors are influenced by non-state criminal networks and narrow private groups to preserve and protect their illicit interests. This entices political elites and public officials to trade in illegal and lucrative black-market commodities such as drugs and arms. This negatively affects the role of the police and their functions are perverted by political and criminal intrusion. Therefore, the police are influenced to protect elite and criminal groups' black market commodities. 
Simultaneously, powerful drug-lords, senior officials and mineral smugglers who are also engaged in such illicit activity retain immunity from prosecution. In particular, the ANP are manipulated by powerful figures to release drug traffickers, killers and thieves. ${ }^{47}$

The drug trade has resulted in weak law enforcement due to the political intrusion of the security and judicial sectors. USIP's Senior Rule of Law Advisor argued that 'the culture of impunity exists today' where drug smugglers with powerful political connections 'are not held accountable' and the courts function in their interests due to bribery or threats. ${ }^{48}$ The Deputy Chair of the Afghanistan Independent Human Rights Commission similarly argued that if notorious drug traffickers are caught then 'the same day they are released either by the police, Attorney General, primary court, Supreme Court or the prison will be issued a decree to release these notorious people'. ${ }^{49}$ Hence, the accused that are released are often notorious drug traffickers. ${ }^{50}$

Once sectors of the state have been infiltrated to serve private criminal interests, systemic corruption linked with the drug trade is hard to fight within Afghan institutions. Afghanistan has weak government institutions and investigation units that lack independence from political intrusion. The Director for Global Rights claimed that the Afghan government clearly does not 'want a truly independent judiciary or anti-corruption agencies' ${ }^{51}$ Due to forms of political intrusion that serve criminal interests, the chiefs of anti-corruption agencies apply flexibility and 'leave cases on the shelf' to avoid certain figures with political connections being held accountable. ${ }^{52}$

\section{Ethnic favouritism}

Favouritism with the ANSF on ethnic grounds, including the police, influences broader policies and local actions and creates popular resentment toward the police forces in particular areas. After 2002, under the then Minister of Interior, Ali Ahmad Jalali, new 
appointments were concentrated in north-west Afghanistan, with very few in the south or east. By the end of 2010, accusations of ethnic favouritism soared under the Tajik Interior Minister Bismillah Khan Mohammadi who 'eased out' many Pashtun officers from the Police Academy. ${ }^{53}$ This has generated competition with rival networks and posts are sold due to the misuse of accumulated state resources.

The central government is hindered by widespread nepotism and corruption. President Karzai alienated Pashtun tribes in largely Pashtun Kandahar by appointing childhood friend Tooryalai Wesa - a fellow of the minority Mohammadzai tribe - as governor instead of an individual from Kandahar's Ghilzai majority tribe. ${ }^{54}$ Therefore, nepotism—namely favouritism - is a consequence of a traditional tribal system that has been imposed on a central government. ${ }^{55}$ This remains prevalent.

Furthermore, the ANP lacks loyalty to the state. A large portion of the force remains loyal only to regional commanders and local warlords rather than the state MoI. ${ }^{56}$ A Research Officer for the Afghanistan Research and Evaluation Unit (AREU) argued that if the ANP 'were formerly loyal to an ex-commander in the north, they are probably still more loyal to that commander than they are to the central government'. ${ }^{57}$ Such loyalty is often based on ethnic grounds.

It is important to note that all of these four types of corruption that frequently occur in Afghanistan are not different levels but rather different forms that are interconnected and overlapping. It must be acknowledged that grand corruption within President Hamid Karzai's family, including drug trafficking and illicit businesses, and petty corruption such as patrolmen extorting bribes to supplement low income are different forms of corruption. However, corruption constantly fluctuates between these four explanations and may range from low levels to high levels of corruption. Hence, the relationship between petty and systemic corruption is a constant trend and the two interact with one another. 


\section{Responses to corruption}

The previous sections covered the forms, perceptions and causes of corruption which allows for a discussion of anti-corruption strategies. This section covers international and Afghan governmental strategies for tackling corruption within the Afghan police force. It initially covers the efforts of Germany and the US over police reform which is followed by MoI efforts to curb corruption, with international assistance, and the challenges faced. The final part covers specific measures to combat corruption in the Afghan police. This includes the central issues of pay reform, meritocratic recruitment and stationing.

\section{International anti-corruption efforts}

In order to assess the effectiveness of anti-corruption strategies, this section begins with an examination of the various initiatives and measures the Afghan government and internationals have introduced. Initially, the Afghan Interim Authority asked Germany to lead police reform due to its previous involvement in providing assistance to the police. However, Germany failed to successfully advance police reforms. The police remained untrained and had poor equipment, while 70-90 per cent were illiterate and remained loyal to warlords and local commanders rather than the central government. ${ }^{58}$ This led to US intervention in 2003 bringing further resources to support electoral processes. This was followed by the establishment of the Combined Security Transitional Command-Afghanistan (CSTC-A) in 2006. CSTC-A have trained and equipped the ANP, as well as the Afghan National Army (ANA), militarily to fight the insurgency rather than the German and European focus on strengthening the rule of law and human rights. ${ }^{59}$

Since 2005, the US army has spent a staggering US\$14 billion to train, reform and equip the ANP. The ANP had 157,000 troops in May 2014 and the aim is to reach up to 162,000 by the end of $2014 .^{60}$ The US has spent an estimated US\$102 over the past decade in an attempt 
to develop Afghanistan in addition to $\$ 6$ trillion from the outset of the invasion. In addition, the international community has donated US\$3.17 billion to the Law and Order Trust Fund for Afghanistan police salaries but wages remain low. ${ }^{61}$

It is also important to point out that the counter-insurgency strategy to combat the Taliban has generally taken precedence over protecting the public. The aggressive behaviour of the ALP debatably attracts further insurgent attacks in rural Afghanistan, as has been prominently argued by President Karzai. ${ }^{62}$ Police corruption has increased support for the Taliban and therefore anti-corruption efforts in the ANP can also be viewed as important in terms of counter-insurgency strategy.

\section{Afghan Ministry of Interior anti-corruption strategy}

In order to combat corruption, the European Union Police Mission in Afghanistan (EUPOL) Anti-Corruption Implementation Plan based in Kabul focuses on capacity-building, prevention (including training) and enforcement. This three-fold strategy is part of the MoI's National Police Strategy. First, building the capacity of the MoI focuses on the institutional systems of merit-based appointments, accountability, procurement, weapons transparency and personal asset exposure. In addition, an adequate police salary is on the agenda to deter corruption and attract high quality candidates that will remain in their posts. Second, prevention is to be enhanced via public awareness campaigns, specialised training and the application of procedures to identify corrupt activities and counter corruption, drugs and illegal armed opposition groups. Third, enforcement is conducted by the MoI via the Attorney General, Inspector General and the Major Crimes Task Force (MCTF) to investigate allegations of corruption cases under the supervision of the Attorney General's Office (AGO). 
The US established the MCTF in November 2009, which has 200 agents to investigate the police in relation to drug and terrorism issues. ${ }^{63}$ However, the MCTF is tarnished by political interference. It is virtually impossible to arrest high-profile and politically connected individuals and this further hinders the fight against corruption. In 2010, President Karzai's close adviser, Muhammad Zia Salehi—head of the National Security Council—was arrested for soliciting a US\$10,000 car as a gift, closing a money laundering investigation of the New Ansari, and providing vehicles and money to presidential allies. Salehi was arrested by the MCTF and Deputy Attorney General and senior anti-corruption lawyer, Fazed Faqiryar. However, Faqiryar was forced to retire and Salehi was released, at the request of President Karzai, for allegedly having his human rights breached. ${ }^{64}$ This case provides ample evidence that the head of state can manipulate anti-corruption staff and assert his political clout during major cases of corruption in order to protect his close political aides.

Despite the investigatory and referral powers that the MoI possesses to curb police corruption, four interviewees argued that the police are heavily involved in extorting bribes and that cases against corrupt officers are often dropped within the MoI. Moreover, drugmules are released from either the police or investigative units due to political interference. ${ }^{65}$ Furthermore, anti-corruption and investigative agencies have little faith in the police to conduct unbiased professional investigations of corruption. Pay reform, meritocratic recruitment and stationing in the Afghan police have been endorsed to combat the four aforementioned explanations of the causes of police corruption.

\section{Pay reform, recruitment and stationing}

The previous section covered international and governmental attempts at police reform and their efforts to curb corruption in the Afghan police. This now allows a section to examine methods of combatting petty corruption and patronage. This section therefore covers the 
general responses on pay reform, recruitment and stationing more specifically. Initially, a background on police training is provided to address some of the issues with corruption prior to an examination on anti-corruption efforts.

In November 2007, the US implemented the Focused District Development (FDD) programme to improve police reform, combat corruption, provide new equipment and enhance the capability of and rule of law within the ANP across 365 districts. ${ }^{66}$ Whilst the district police were being trained, all untrained recruits were brought to a Regional Training Centre for the AUP for eight weeks under the supervision of Police Mentoring Teams. ${ }^{67}$ However, police behaviour remains poor due to the excessive use of coercion, corruption and extortion.

Institutional reform in the MoI has included pay and rank reform to notably reduce corruption and patronage. This was implemented at the end of 2005. The ranks were previously 'top heavy' due to appointments based on patronage, resulting in too many generals, colonels, captains, majors and very few lieutenants. ${ }^{68}$ After pay reform, the lowest scale of the AUP, patrolmen, had increased in size from 36,600 to 45,880 , but the wages remained low at US\$70-80 per month. ${ }^{69}$ This is a cause for concern as the majority of the ANP consists of patrolmen. Pay reform thus risks failing to break the cycle of survival-based corruption at the lowest levels in the ANP.

The phases of rank reform are intertwined with meritocracy as an anti-corruption measure. A Selection Committee was established to implement tests and a vetting process to disband unqualified police officers. This process has been adopted with the selection of 34 provincial CoP positions. Yet, it was neglected by President Karzai through the June 2006 decree when 14 police chiefs and 86 generals who failed the entry examination were appointed. ${ }^{70}$ This included four persons linked with illegal armed groups that were also barred from parliamentary elections. In addition, others included renowned human rights 
violators, narcotics traffickers and warlords, and several were involved in government corruption, bribery and interference in police investigations. ${ }^{71}$ These provincial police chiefs and generals should have been investigated for human rights violations and corruption rather than being arbitrarily appointed.

Candidates with low levels of literacy regularly fake qualifications and change their ethnic backgrounds for the recruitment of an ethnically balanced and diverse police force that is proportional to the population. As a consequence, large numbers of corrupt and incompetent individuals linked with leading power groups in the MoI and cabinet enter the ANP which hinders meritocracy. ${ }^{72}$ United Nations Office on Drugs and Crime (UNODC) sectored surveys also suggest that 54 per cent of the ANP received assistance in recruitment and eight per cent paid bribes. ${ }^{73}$ In Jalalabad, the 'admission, selection, appointment and promotion' processes are not based on merit but rather corruption and, across Afghanistan, police are 'selected, appointed and promoted'. ${ }^{74}$ This is due to their affiliation with warlords and high-level corrupt government officials, with bribes expected in such processes.

Loyalty and patronage still persist. In particular, the recruitment of local police and irregular militias at the provincial and district levels are beyond the overly centralised Afghan government. Irregular militias are recruited rather than the police from Karzai's cabinet. For example, ex-human rights violator Ismail Khan, Minister of Water and Energy since 2005 in Herat, appoints militiamen that are loyal and serve his interests.

Afghan police officers purchase the post where they want to be assigned. This is usually in areas where there are opportunities to engage in petty corruption such as extorting bribes from cart vendors selling produce in main cities. ${ }^{75}$ Moreover, the police officers pay to work in high poppy cultivating areas in order to work within the border patrol force to extort bribes from merchants and truckers involved in smuggling. ${ }^{76}$

Anti-corruption strategies have focused on limiting ethnic and tribal discrimination 
within the ANSF. Alikuzai claims that this is to ensure that certain ethnic groups or individuals from 'particular regions' who lack access to influential power brokers in highlevel commands 'are not selectively posted' to extremely hostile 'areas for too long without being rotated out' and that commands are not dominated by Tajiks or another particular ethnic group. ${ }^{77}$ The MoI suggests that its own ministry is extremely politicised and wellconnected illiterate provincial police chiefs with no police experience or qualifications are appointed, namely by President Karzai. The MoI also claim that resources are diverted within the ministry and the loyalty of senior officers to the police is relatively unknown. ${ }^{78}$ Afghan citizens claim that the MoI officials, provincial police chiefs and ordinary ANP are involved in the opium trade. There are various reports of senior MoI officials selling provincial and district senior police posts to the highest bidders and protecting narcotics traffickers in exchange of receiving large bribes. ${ }^{79}$

Systemic corruption linked to tribal ties and provincial or local loyalties has been internationally recognised. In order to address this issue, lottery assignments for new ANP recruits were installed by the MoI with the assistance of CSTC-A to place police in random provinces to reduce patronage networks, tribal, ethnic, familial and political ties. A centralised national recruitment programme was implemented to prevent graduates of Regional Training Centres returning to the province where they were initially recruited. The February 2010 lottery assignment system has been implemented with cadets of the National Military Academy of Afghanistan at their graduation to prevent personnel buying positions from corrupt ANA officer corps. ${ }^{80}$ The strategy also increases the transparency of assignments and ensures that personnel are assigned randomly to all Afghan regions.

Despite such efforts, elder selections may be based on personal, ethnic and other partisan interests. These selections are part of a qawm system ${ }^{81}$ to provide loyalty to the appointer which overrides meritocratic appointments. Elder selection involves a local elder vouching 
for police candidates to be selected in their province. This mechanism applies mainly to the ALP, not AUP. Policemen with good relations with senior ranked police officers, a CoP, local governor or tribal elder can easily be posted to the province of their choice. Posting can therefore be based on loyalty or paying to work in the desired province with a lump sum or monthly payments to the appointer via a stipend of bribes collected ${ }^{82}$ Hence, corruption, loyalty and patronage still remain with recruitment, meritocracy and stationing of the ANP.

Based on this overview of the central facets of the major anti-corruption strategies, the following section will critically examine pay reform, recruitment, stationing and broader anticorruption strategies with specific reference to the surveys conducted.

\section{Analysis}

In the previous sections, the causes of corruption and anti-corruption strategies have been addressed. This section analyses the surveys conducted with 100 low-ranked policemen in Kabul, Logar, Laghman and 12 other provinces. The analysis is divided into two separate parts. The first considers key variables, identified in survey findings, such as living costs, expenses, salary and the number of breadwinners per household that help to account for the pervasive corruption identified in the earlier sections of the article. These are the determinants of corruption. The second part considers stationing strategy. A factor in the initial variables is the number of earners per household which may be affected with random assignment. The survey respondents' perceptions of corruption and anti-corruption strategies will be reflected upon, considering, for instance, whether they felt wages were sufficient to cover living costs and the influence of patronage relations on appointments. Such perceptions provide important insights into the dynamics of survival-based corruption and the reasons behind lottery assignments. It is the perceptions and empirical evidence that will be analysed 
in relation to both causes of corruption, a deficit of wages and stationing of policemen. The end of the analysis will, however, demonstrate the contradictions of random assignments.

\section{Determinants of corruption}

This section analyses the possible determinants of corruption in order to convey certain trends that may impact on corruption such as wages being too low to cover total expenditure and patrolmen being stationed with large families in distant provinces. According to survey respondents, the main determinant of corruption is wage deficiency and other variables add to the economic hardship that low-ranked Afghan policemen face.

The surveys show that the average number of family members per household is 11.5 and solely for patrolmen it is 11 . Hence, the majority of the policemen surveyed have large families ${ }^{83}$ Alongside large families, 48 out of 52 respondents lived in owned housing with an average of 5.5 rooms per household and the average number of breadwinners per household is 2.45 . For patrolmen, most (42 out of 76) live in rented accommodation with 34 out of 76 in owned housing and the average number of breadwinners per household is 2.3 . Taking this into consideration, the families are large, many family members share rooms and there are no more than two household earners on average. This means that the wages will have to be sufficient for the breadwinners to cover the total expenses for large families. The total living costs, expenses and wages earned will now be addressed.

The average salary of the 100 low-ranked police respondents is 12,824 AFN per month with an average total cost of living of 17,570 AFN per month. This means that there is an amount of 4,746 AFN that is required to supplement the low wages in order to cover the total expenses of large families, particularly if there is only one breadwinner. ${ }^{84}$ In relation to the 76 patrolmen, the average number of family members is 11 with monthly wages at 12,008 AFN and expenses at 15,237 AFN per month. This means that there is a deficit of 3,229 AFN per 
month for patrolmen. This data implies that the deficiency of wages to cover total living costs and expenditure can exacerbate modes of petty corruption as supplementary measures for low salaries.

Various examples from the respondents confirm the existence of the issue of wage deficiency to cater for living costs and expenses. To offer one example from many, a patrolman working in Paktia earns 12,000 AFN per month to cater for 11 family members as the sole breadwinner in owned accommodation with total living costs of 15,000 AFN monthly. This is a 3,000 AFN wage deficit. Hence, the patrolman claimed that his salary was not adequate to cover his living costs. In addition, he had been working as a patrolman for 18 months and had not undergone any pay and rank reform. Consequently, his salary had remained the same and he stressed that bribery and roadside extortion are the main practices of corruption in the ANP due to low wages. This case and numerous other such examples provide tentative evidence that when wages are too low to pay for the total costs of living and expenses, corrupt practices such as bribery and roadside extortion can result due to the economic hardship associated with low wages.

There were similar findings on possible causes and practices of petty corruption related to low wages. The main forms of corruption that the survey respondents listed were: weak oversight and implementation of disciplinary procedures (reported by half of the respondents); low pay from 22 out of the 100 lower ranked policemen ( 22 per cent) ${ }^{85}$ bribery and roadside extortion from 20 per cent; embezzlement of funds from 10 per cent and greed and selfishness from only two per cent. In relation to perceptions of levels of corruption in the ANP, 38 per cent of the respondents thought that it is low, 32 per cent suggested that corruption is medium, 22 per cent believed that corruption is non-existent, six per cent perceived that it is high and two per cent claimed that the level of corruption is extreme in the ANP. These findings indicate that the policemen believed that oversight and punitive 
sanctions were poor and low pay and forms of petty corruption were the main forms of corruption. The correlation of low pay and petty corruption may indicate that practices such as bribery and roadside extortion may be to supplement low wages.

In response to questions that asked how respondents might improve pay and rank reform and anti-corruption strategies, a number of ideas were put forward. Many respondents stated that higher salary increments would help to cover all living costs and provide motivation for good performance and behaviour. For instance, a first lieutenant working in Logar and a patrolman working in Kapisa claimed that low pay is a factor that causes corruption in the Afghan police. In addition, a second lieutenant from Kabul claimed that higher salaries for government employees were needed to reduce corruption in the ANP. A patrolman working in Panjshir stressed that strong oversight and monitoring of the recruitment process and higher salaries are needed to reduce corruption in the Afghan police institution. Furthermore, a patrolman working in Kabul stated that his salary is 'slightly short to fulfil daily life' and that 'increasing police salaries in the lower ranks can finish corruption'.

Family structure was another issue identified by respondents as importantly impacting anti-corruption efforts. Large families rely on more than one breadwinner to cover living costs. For all of those that were the sole breadwinner (18 of the respondents), only two first lieutenants and one patrolman stressed that they were able to cover the total expenses of the household with their salary. One of the first lieutenants working in his home province, Logar, by his own request earns 13,500 AFN per month that covers his 8,000 AFN monthly living costs and expenses for eight family members in owned accommodation (consisting of five rooms). The other first lieutenant working in his home province, Kunduz, by qawm, familial or political ties earns 13,500 AFN per month that covers 10,000 AFN monthly total costs for six family members in owned accommodation (consisting of four rooms). In addition, a patrolman working in his home province, Kapisa, by his own request earns 10,500 AFN that 
covers 5,000 AFN total monthly living costs and expenses for eight family members in owned housing (consisting of three rooms). In these three cases, even though there is only one breadwinner per household, the salary is high enough to cover low total living costs and expenses. This provides empirical evidence that wages in the lower ranks were sufficient to cover the living costs and expenses of large families. However, these perceptions of sole breadwinners are only based on three of the survey respondents and therefore the other 15 breadwinners struggled with financial costs.

The remainder of lone breadwinners suggested that they could not cover all of their costs with their wages. For instance, a second lieutenant from Kabul earns 18,000 AFN monthly but pays 30,000 AFN per month for living costs and expenses for 18 family members. This lieutenant stressed that he could not afford the expenses of daily life financially as he was the only breadwinner of the household. Moreover, a patrolman working in Kabul pays 12,000 AFN per month in living costs and expenses but only earns 11,000 AFN as the sole breadwinner for seven family members. These responses emphasising insufficient wages, principally for lone breadwinners, to cover living costs and expenses suggests that these policemen find it difficult to survive. Hence, there is a high possibility that salary supplementation will be a necessity to cover costs such as engagement in petty corruption.

On the other hand, if there is more than one breadwinner then the policemen claimed that they were able to cover their total living costs and expenses due to support from another family member - namely brother or father. To illustrate, a patrolman working in Logar earns 11,500 AFN per month to contribute to 15,000 AFN monthly for living costs and expenses. However, the living costs and expenses are affordable due to two salaried household members including his father. Similarly, a first lieutenant that works in Kabul pays 20,000 AFN in monthly expenses (for 13 family members) with a monthly salary of 14,500 AFN. 
Despite a 5,500 AFN deficit, he could afford expenses and living costs due to three breadwinners within the household.

Even in instances where there was more than one breadwinner per household working in a home province who earned less than their monthly expenses but could afford expenses due to additional salaries within the household, these respondents recognised that it would be difficult if they were the sole earner. For instance, a patrolman working in his home province, Khost, (who could afford his expenses due to two breadwinners) claimed that salaries should be increased to reduce corruption in the ANP due to the fact that it is tough for one breadwinner to cover all living costs. In addition, a patrolman working in Kabul with the support of five additional earners within the household also acknowledged that covering total living costs and expenses would be difficult in households that only have one salaried person. ${ }^{86}$ Similarly, a patrolman from Nangarhar suggested that his 500 AFN monthly deficit of wages for living costs and expenses was affordable due to two breadwinners but it would be tough if he was the only breadwinner.

According to the surveys conducted, it can be argued that pay reform has made little difference at the lower levels of the Afghan police. Patrolmen/non-ranked street police still have low wages and a limited amount of money to pay for the cost of living, unless there is more than one breadwinner per household. The former Afghan Minister of Interior claimed that he needed more time to 'improve the living conditions of the police force, especially assisting them with a housing scheme and also health care' to combat petty corruption. ${ }^{87}$

\section{Stationing strategy}

The analysis so far has provided perceptions and empirical evidence that suggests that low wages, particularly when there is only one earner per household, can lead to corrupt practices. This is to supplement income in order to cater for living costs and expenses for large families. 
Therefore, strategies to curb corruption are needed such as pay reform which may reduce petty corruption. Yet, there are also other forms of corruption that were emphasised by the survey respondents when questions were asked about attempts to challenge police corruption.

On the subject of anti-corruption strategies, only five of the survey respondents knew what the MoI anti-corruption strategy entailed. The main strategies to combat corruption in the Afghan police, as indicated by the respondents, consist of providing strong oversight/monitoring of the police to hire and select more honest staff. The respondents expressed that better screening will not only lead to the hiring of more honest staff, but will also avoid police recruitment based on personal relations. This is informative as an indication of MoI strategies that have failed to be understood by the lower levels of the police force but it was acknowledged that patronage relations leading to appointments hinder the meritocratic credibility of the ANP.

It is clear from the analysis that the stationing strategy has been implemented due to concern regarding the influence of patronage relations in relation to appointments. This became clear from the respondents of the surveys. Patronage was well emphasised as an occurrence in relation to appointments and stationing. Seventy-eight of the policemen, excluding the 22 that were randomly assigned to an away province, obtained their positions through patronage mechanisms via elder and officer selections, qawm ties and by their own request. These methods of stationing are associated with favours to the appointers. Thirty-six of the survey respondents claimed that the positions of ANP and MoI staff are patronagebased and that staff are appointed on the basis of factional, kinship or ethnic ties.

For those who thought that patronage in recruitment occurs in the ANP (36 per cent), it was perceived that patronage mainly persists in MoI positions. It was also stressed by these respondents that if a policeman knows a commander or a high rank officer, then that policeman will get more salary increments and promotions. These respondents' insights 
included a friend or academy class fellow having entered high positions due to good relations with senior staff or a commander. For instance, a second lieutenant (who works in his home province, Kabul, by officer selection) stressed that patronage existed as one of his friends was employed by a personal relation. ${ }^{88}$ In addition, a patrolman working in Panjshir believed that patronage appointments were prevalent in the ANP and MoI. The patrolman provided an example of a friend who knew a commander that admitted him into a position.

The perceptions of patronage were similar to the above findings when policemen were randomly assigned to another province under the lottery system. To illustrate, a non-ranked policeman who was randomly assigned to Nangarhar, an away province, claimed that patronage was prevalent in the ANP and MoI staff. He provided an example of one of his academy classmates attaining a high rank due to good relations with high authorities.

As a result of the perceptions of patronage obtained from the survey respondents and the wider literature, as analysed previously, stationing has been endorsed in the Afghan police to challenge the influence of patronage-based appointments. Patronage has repercussions on both meritocracy and loyalty to the state. Now that the perceptions of patronage have been addressed, the remaining parts of this analysis will cover the methods of stationing, as part of efforts to curb patronage-based corruption, and the repercussions that it has on overall anticorruption strategies.

There are various measures concerning the location of policemen that may have an impact on corruption. Fifty-two per cent of survey respondents work in their home province and 48 per cent work in an away province. For patrolmen, 40 out of 76 work in an away province and 36 work in their home province. There are six ways that the ANP can enter their posts in certain locations: (1) by their own request; (2) elder selection; (3) officer selection; (4) qawm, familial or political ties; (5) the lottery (random) system; and (6) paying for a location. Of the survey respondents, 44 per cent were posted by their own request; 22 per cent 
by the lottery (random) system; 18 per cent by elder selection; 10 per cent by qawm, familial or political ties; four per cent by officer selection and two per cent paid for their location. For patrolmen, 32 out of 76 (42 per cent) suggested that they were posted in their location by their own request; 26 per cent by the lottery (random) system; 18 per cent by elder selection; eight per cent by qawm, familial or political ties; three per cent by officer selection and three per cent paid for their location.

There is some correlation between a home and away province when an officer is posted by their own request. Twenty-four out of 44 of the policemen were posted by their own request within their home province and 20 out of 44 in an away province. For patrolmen, 18 out of 32 were posted in their home province by own request and 14 out of 32 in an away province. This means that the majority of policemen prefer to be posted in their home province which is arguably due to pre-exiting connections and a better likelihood of having owned accommodation. In addition, there may be further economic support with wider family structures in a familiar province.

Yet, when analysing the data in Kabul, 10 out of 16 policemen that were posted by their own request opted for their home province-Kabul. In addition, six out of the 10 policemen that were working in Kabul and posted by their own request from away provinces requested to move and work in Kabul. When comparing the wages with other provinces, they were similar and sometimes even lower.

Therefore, there are certain motivations that lead to policemen requesting to be stationed in Kabul. As these findings strongly suggest, a major factor appears to be better opportunities such as extorting more bribes from street vendors and passing vehicles for bogus offences. Subsequently, a stipend of the bribes collected is paid up the chain of command to the CoP or other senior officers. ${ }^{89}$ In addition to opportunities for bribery, other important factors which lead recruits and officers to demand posting to particular areas include the level of insecurity 
and physical risk. Related to both is the distance and risk involved in travelling to visit one's family.

All of the elder selections led to the appointment of policemen in their home provinces. In Nangarhar, elders hold powerful influence concerning the appointment of patrolmen according to the six surveys conducted in the province. ${ }^{90}$ Five out of six policemen, all patrolmen, were selected to work in their home province by elder selection and the other one was randomly assigned to work in Nangarhar. With qawm, familial or political ties, only two out of 10 (both patrolmen) were posted in an away province. In relation to officer selections, two out of four policemen were posted in home provinces. There were two instances whereby survey respondents admitted that they had paid to be stationed in an away province. To provide one example, a patrolman working in Panjshir claimed that he had paid to move from his home province. ${ }^{91}$

In relation to the second highest method of posting policemen, the lottery (random) system, all of the respondents were posted in away provinces. This is to reduce patronage networks, qawm advantages and loyalty by serving the interests of an elder, officer or commander. Moreover, this is designed to combat the practice of policemen paying to be stationed in a preferred location. Many of the lottery assigned policemen have a slightly lower ratio of breadwinners per household - two per household. Only six out of the 22 are the only breadwinner per household and all reside in rented accommodation. In all of these cases, the policemen claimed that their salary was insufficient to cater for living costs and family expenses.

For example, a patrolman who applied to his nearest department of police was randomly posted to Kapisa. He claimed that his salary was not enough to cater for living costs and expenses because he is the only breadwinner. ${ }^{92}$ Furthermore, in one instance where there are two breadwinners for a household with a large family in an away province due to the lottery 
system, it is still difficult to cater for living costs and family expenses. To specify, a patrolman working in Logar by lottery assignment claimed that his salary is too low to cover high monthly living costs and family expenses despite having two breadwinners within the household. ${ }^{93}$ It can therefore be argued that policemen that are randomly assigned under the lottery system to an away province struggle to pay for living costs and family expenses if they are the sole breadwinner. This is also the case in some instances if there are two breadwinners. ${ }^{94}$

Although the lottery system was designed to reduce clientelism and patronage networks, it may negatively impact anti-corruption strategies. According to the results of this survey, the police would have to be paid more or provided with governmental housing (where there is no second earner) otherwise this system runs the risk of further survival-based corruption for economic necessity even if pay is increased.

This suggests that lottery assignments are also counterproductive. The strategy removes policemen from family support networks and they are often forced to survive as the only breadwinner in, most likely, rented accommodation. The survey results support the claim that the police that are assigned away from their home province cannot afford living expenses as a sole breadwinner. However, if the police work in their home province, then their father or brother can help to cover expenses and that potentially reduces the risk of survival-based corruption, namely bribery and roadside extortion.

This research points toward important measures that could help to enhance anticorruption strategies by emphasising the way pay reform and meritocracy need to work together. This is especially apparent where it has proven counterproductive to post policemen to distant provinces if there is no relative to help with living costs. Such practices pose the risk of encouraging patrolmen's engagement in corrupt and illicit activities to supplement wages to cover living costs. In terms of anti-corruption, the MoI has focused on meritocracy 
and challenging clientelism through provincial random assignment. However, the police that are randomly assigned in provinces away from their homes and even some policemen working in their home province will struggle with their salary as a sole breadwinner. The analysis presented above indicates that random stationing may exacerbate survival-based corruption if low-ranked policemen are sent away to another province and if they are the sole breadwinner. Hence, the analysis points to two causes of corruption, from the perceptions and empirical evidence, which are wage deficiency and stationing.

\section{Conclusion}

This article has sought to demonstrate the many damaging effects of corruption and clientelism within Afghanistan's Interior Ministry, focusing on the police. Such practices have resulted in petty bribery, extortion, ethnic favouritism and infiltration by political elites affiliated with drug traffickers. Low wages in the ANP have led to survival-based corruption. Customs officials, border police and uniformed police are vulnerable to bribes from narcotics traffickers and other criminal groups. 'Corruption in the voting processes' during elections has delegitimised state officials in the eyes of the Afghan public and this can be identified as a driver of Taliban remobilisation. ${ }^{95}$ These features are also hindering the effectiveness, efficiency and competence of the police and MoI.

In relation to senior police, $\mathrm{CoP}$ posts in poppy-rich districts are sold to the highest bidder willing to provide protection to narcotics traffickers at a going rate of US\$100,000 for a six month post with a $\$ 60$ per month clean salary. The MoI can be thought of as a market that sells police posts to the highest bidder- this arguably confirms its reputation as Afghanistan's most corrupt institution. ${ }^{96}$ Endemic corruption, clientelistic relations and the accumulation of state resources have increased both 'inter-factional competition' and 'costs 
of appointments', and the sale of posts and protection is also present in the Presidential Office. $^{97}$

The internal MoI anti-corruption strategy has attempted to curb corruption within the police through the operation of various investigation units. However, in high drug-related cases that are transferred to the MCTF and other units such as the High Office of Oversight and Anti-Corruption (HOOAC), political interference influences the cases and many are dropped due to cronyism. ${ }^{98}$ This is a consequence of state capture. The Afghan state has been infiltrated by the narrow interests of non-state criminal networks and powerful elites linked with the illicit and lucrative opium trade that manipulates law enforcement, anti-corruption and all investigation, security and judicial duties. It is also important to stress that there are many forms of corruption and politicisation which are not linked to poppy cultivation and opium trafficking such as land theft, custom evasion, seizure and misappropriation of foreign aid, state resources, jobs and economic benefits.

This article has demonstrated that pay reform does have the potential to reduce corruption, particularly in the lower levels of the ANP. According to the surveys with 100 Afghan policemen, mainly patrolmen and some lieutenants, increasing salaries can significantly reduce survival-based corruption in the lower ranks. Lottery assignments have been installed as a measure to eliminate patronage-based corruption and loyalty to warlords and local commanders. Yet, this can be counterproductive. Low-paid policemen stationed in another province away from their home in rented accommodation are less likely to have financial support from a father or brother. As a consequence, the policemen in this situation may struggle to cater for the rent and total familial expenses for large families. This can therefore exacerbate lower levels of corruption as a means of economic necessity. Pay reform and lottery assignments need further reforming if they are going to seriously reduce both corruption and clientelism. 
Pay reform has the potential to combat petty corruption in the lower ranks but systemic corruption, clientelism and state capture will remain unchallenged with a linear approach. Hence, increasing the salaries of Afghan policemen would reduce corruption but not significantly. If wages were increased with pay reform as a singular anti-corruption strategy, patronage relations would persist and oversight, disciplinary and internal anti-corruption strategy issues that were prioritised by the ANP survey respondents would remain.

High corruption levels in the ANP and the government has reduced the legitimacy of the state in the eyes of Afghans. It has also been contended that this has led to Taliban resurgence. With the Karzai era coming to a close, it is imperative that the new Afghan President, either Abdullah Abdullah or Ashraf Ghani Ahmadzai, focuses on a robust anticorruption strategy within the police force in order to rebuild trust in the police and state. This may deter support for the Taliban. Anti-corruption, particularly in this context, serves as a broader peace-building strategy and if this is not taken seriously by the new Afghan President then the conflict will remain unresolved, stagnating the post-war recovery process and wider development.

\section{Acknowledgements}

The author is grateful to all of the participants involved in this study and especially to colleagues within the Post-war Reconstruction and Development Unit (PRDU), Dr Tom Waldman and Bradley Lineker, for reviewing earlier drafts of this article.

\section{Endnotes}

\footnotetext{
${ }^{1}$ Carter and Clark, No Shortcut to Stability, 11; Tomsen, The Wars of Afghanistan, 643.

${ }^{2}$ Giustozzi and Isaqzadeh, Policing Afghanistan, 89.
} 
${ }^{3}$ See Wilder, Cops or Robbers?; and Planty and Perito, Police Transition in Afghanistan.

Both are studies of Afghan police corruption consisting of interviews conducted with senior Afghan and US officials working on ANP development.

${ }^{4}$ Nationwide Afghan protests commenced after US actors burned copies of the Quran at Bagram North Atlantic Treaty Organisation (NATO) Air Base. This led to the deaths of two US military trainers and at least 29 Afghans. NATO immediately withdrew hundreds of military trainers from Kabul's MoI (Al Jazeera, 'United States Officers Killed in Kabul's Interior Ministry'. Al Jazeera, 25 February 2012; Graham Bowley, 'Two American Soldiers Die in Shooting at Afghan Base'. The New York Times, 6 August 2012). In addition, numerous coordinated Taliban attacks in the Wazir Akbar Khan area of Kabul targeted US and United Kingdom Embassies and the MoI.

${ }^{5}$ Interview former Minister of Interior, York, 23 November 2010.

${ }^{6}$ Chêne, Overview of Corruption in Pakistan, 5.

${ }^{7}$ Nojumi et al., Afghanistan's Systems of Justice, 29.

${ }^{8}$ Barakat et al., A Strategic Conflict Assessment, 25, 42.

${ }^{9}$ Giustozzi and Isaqzadeh, Policing Afghanistan, 92.

${ }^{10}$ Pothier, Opium in Afghanistan, 14.

${ }^{11}$ Hafvenstein, ‘Afghanistan's Opium Strategy Alternatives’, 125.

${ }^{12}$ Interview Operations Officer for the World Bank's Afghanistan Reconstruction Trust Fund, Kabul, 5 June 2010.

${ }^{13}$ Interview Senior Rule of Law Advisor for USIP, Kabul, 30 May 2010.

${ }^{14}$ Barakat et al., A Strategic Conflict Assessment, 25.

${ }^{15}$ Checchia, 'Corruption and the Afghan Security Forces', 40.

${ }^{16}$ Interview Head of Transitional Justice for the United Nations Assistance Mission in Afghanistan: Human Rights Unit, Kabul, 1 June 2010. 
${ }^{17}$ Giustozzi and Isaqzadeh, Afghanistan's Paramilitary Policing in Context, 17-18.

${ }^{18}$ Giustozzi and Isaqzadeh, Policing Afghanistan, 106-107.

${ }^{19}$ Interview worker for MAIL: Accelerating Sustainable Programme (ASAP), Kabul, 25 May 2010.

${ }^{20}$ In July 2009, a survey was conducted by the Afghan Centre for Socio-Economic and Opinion Research consisting of 5,156 persons aged 18 years or over (with an almost equal sex ratio) across all 34 Afghan provinces over 12 days.

${ }^{21}$ UNDP, Police Perception Survey 2009, 5-6, 20.

${ }^{22}$ IWA, Afghan Perceptions and Experiences of Corruption, 23.

${ }^{23}$ Interview Country Director of Flag International Afghanistan, Kabul, 26 May 2010; IWA, Afghan Perceptions and Experiences of Corruption, 23.

${ }^{24}$ IWA, Afghan Perceptions and Experiences of Corruption, 9.

${ }^{25}$ Cliffe and Roberts, World Development Report 2011, 133.

${ }^{26}$ IWA, Afghan Perceptions and Experiences of Corruption.

${ }^{27}$ Interview Head of Access to Justice Programme for The Asia Foundation, Kabul, 26 May 2010.

${ }^{28}$ Ibid., 11.

${ }^{29}$ Engelhardt, The United States of Fear, 137.

${ }^{30}$ Chris Sands, 'Bring Back Taliban to End Police Corruption'. The Independent, 10 May 2007.

${ }^{31}$ Nathan, 'Reading the Taliban', 35.

${ }^{32}$ Felbab-Brown, Aspiration and Ambivalence, 39-59.

${ }^{33}$ Goodhand and Hakimi, Counterinsurgency, Local Militias, and Statebuilding, 13-15.

${ }^{34}$ Peters, How Opium Profits the Taliban, 31.

${ }^{35}$ UNDP, Police Perception Survey 2009, 20. 
${ }^{36}$ See Olivier de Sardan, 'A Moral Economy of Corruption' for a discussion on nepotism, clientelism and patronage within a 'moral economy' of neo-patrimonial states.

${ }^{37}$ Interview Director of AIAS, Kabul, 26 May 2010.

${ }^{38}$ Interview worker for MAIL: Accelerating Sustainable Programme (ASAP), Kabul, 25 May 2010.

${ }^{39}$ Interview Head of Access to Justice Programme for The Asia Foundation, Kabul, 26 May 2010.

${ }^{40}$ Gupta, 'Blurred Boundaries', 392; Ruud, Corruption as Everyday Practice', 4.

${ }^{41}$ Azami, 'The Need for Security Sector Reform'; IWA, Afghan Perceptions and Experiences of Corruption.

${ }^{42}$ Interview JSSP Legal Consultant to the AGO, Kabul, 29 May 2010.

${ }^{43}$ Interview Project Coordinator of CPHD, Kabul, 27 May 2010.

${ }^{44}$ Interview JSSP Legal Consultant to the AGO, Kabul, 29 May 2010.

${ }^{45}$ Interviews Deputy Country Coordinator and Legal Researcher of the Max Planck Institute for Comparative Public Law and International Law, Kabul, 27 May 2010; Chairman of Afghanistan Human Rights Organisation (AHRO), Kabul, 31 May 2010.

${ }^{46}$ Interviews Peacebuilding and Public Relations Manager of Afghan Civil Society Forum (ACSFo), 1 June 2010; Advisor of the HOOAC, Kabul, 4 June 2010.

${ }^{47}$ Lansford, 9/11 and the Wars, 152.

${ }^{48}$ Interview Senior Rule of Law Advisor of USIP, Kabul, 30 May 2010.

${ }^{49}$ Interview Deputy Chair of AIHRC, Kabul, 27 May 2010.

${ }^{50}$ Interview Deputy Executive Director of MRRD: Afghanistan Rural Enterprise

Development Programme (AREDP), Kabul, Tuesday 1 June 2010.

${ }^{51}$ Interview Country Director of Global Rights-Partners for Justice, Kabul, 3 June 2010.

${ }^{52}$ Interview Advisor of the HOOAC, Kabul, 4 June 2010. 
${ }^{53}$ Giustozzi and Isaqzadeh, Policing Afghanistan, 105-106.

${ }^{54}$ Pape and Feldman, Cutting the Fuse, 124.

${ }^{55}$ Emadi, Culture and Customs, 40.

${ }^{56}$ Sedra, 'Small Arms and Security Sector Reform', 171.

${ }^{57}$ Interview Research Officer: Transitional Justice for AREU, Kabul, Wednesday 26 May 2010.

${ }^{58}$ Murray, 'Police-Building in Afghanistan'.

${ }^{59}$ Interview Senior Advisor to the Minister at the MoI, Kabul, 6 June 2010; Larivé, 'From Speeches to EU Actions', 190-196; Giustozzi and Isaqzadeh, Policing Afghanistan, 49. ${ }^{60}$ Planty and Perito, Police Transition in Afghanistan, 1; Hughes, The Afghan National Police, 3. Katharine Houreld, staff reporter with Reuters, reports that despite an increase in police forces the majority of them push entire districts toward the Taliban due to police abuses ('Afghan Police Take First, Faltering Steps in Fight against Corruption'. Reuters, 25 April 2013).

${ }^{61}$ Eugene Mulero, 'Watchdog: "We Don’t Even Know What We Spend” On Afghanistan Reconstruction'. Huffington Post, 20 March 2014.

${ }^{62}$ Goodhand and Hakimi, Counterinsurgency, Local Militias, and Statebuilding, 39.

${ }^{63}$ Interview Senior Advisor to the Minister at the MoI, Kabul, 6 June 2010. The MCTF is a unit that works with the Federal Bureau of Investigation, Scotland Yard and EUPOL to both investigate and prosecute high profile cases concerning corruption, organised crime and abduction.

${ }^{64}$ Jon Boone, 'Karzai “Fired” Anti-Corruption Lawyer after Top Official Stung'. The Guardian, 30 August 2010. 
${ }^{65}$ Interviews Deputy Chair of the AIHRC, Kabul, 27 May 2010; Deputy Executive Director of MRRD: AREDP, Kabul, 1 June 2010; Peacebuilding and Public Relations Manager of the ACSFo, Kabul, 1 June 2010; Advisor of the HOOAC, Kabul, 4 June 2010.

${ }^{66}$ Cordesman et al., Winning in Afghanistan, 102.

${ }^{67}$ Leonard, United States Plan, 26.

${ }^{68}$ Giustozzi and Isaqzadeh, Policing Afghanistan, 150.

${ }^{69}$ Wilder, Cops or Robbers?, 39.

${ }^{70}$ Wilder, Cops or Robbers?, 40-41.

${ }^{71}$ Wilder, Cops or Robbers?, 40.

${ }^{72}$ Giustozzi, 'Shadow Ownership and SSR', 225-226.

${ }^{73}$ UNODC, Corruption in Afghanistan, 20.

${ }^{74}$ Royal United Services Institute for Defence and Security Studies, Reforming the Afghan National Police, 10.

75 Axe, 'For Urban Afghans'.

${ }^{76}$ Bayley and Perito, Police Corruption, 5.

${ }^{77}$ Alikuzai, A Concise History of Afghanistan.

${ }^{78}$ Planty and Perito, Police Transition in Afghanistan, 10.

${ }^{79}$ Bayley and Perito, Police Corruption, 2.

${ }^{80}$ Brummet, US Reconstruction Efforts in Afghanistan, 16.

${ }^{81}$ Qawm refers to a social unit that may be interpreted as a tribe. This unit can be based on familial and ethnic ties, kinship, a clan, residential locality or social status/occupation. Qawm therefore concerns any practice of solidarity which is governed by a traditionally-based council such as a Jirga or shura (Goodson, Afghanistan's Endless War, 19).

${ }^{82}$ Interviews Head of Access to Justice Programme for The Asia Foundation, Kabul, 26 May 2010; Senior Rule of Law Advisor of USIP, Kabul, 30 May 2010. 
${ }^{83}$ The lowest number of family members per household is five (reported by two of the participants) and the most is 22 members (reported by two of the respondents). Yet, according to some sources, the average household size in Afghanistan is eight members and the average number of children per childbearing woman is 5.5 children (Spilsbury, Discover Afghanistan, 12). Another study conducted by Belay for the World Bank, based on 553 households interviewed in central and rural districts of Badghis, Baghlan, Laghman, Logar and Nimroz, found that the highest average number of family members per household is seven (Belay, Building on Early Gains, 161). Ghafoori et al. cite the results of the SocioDemographic and Economic Survey—-the national average of persons per household is 7.3 (Ghafoori et al., 'Milestone in the History'). Therefore, due to the small sample size and lack of robust tests on statistical significance, the average number of family members amounting to 11.5 based on the surveys conducted by the research team may not be thoroughly representative and thus 7-8 may be more accurate. What is argued here is that Afghans generally have large families per household.

${ }^{84}$ This is only an assumption based on the small sample size and is not generalisable. ${ }^{85} 100$ surveys were conducted with lower ranked policemen. Therefore, percentages will be used for simplification. However, these percentages are only based on the 100 surveys conducted which do not provide any indication of being representative of an entire province. ${ }^{86}$ This patrolman resides in owned accommodation that contains eight rooms for a staggering 22 family members and earns 11,500 AFN per month to pay towards 25,000 AFN monthly living costs and expenses.

${ }^{87}$ Interview former Afghan Minister of Interior, York, 23 November 2010.

${ }^{88}$ This second lieutenant lives in owned accommodation consisting of eight rooms for 16 family members and earns a monthly salary of 17,000 AFN to pay towards 30,000 AFN monthly family costs. Despite a 13,000 AFN deficit, the second lieutenant stressed that he 
could cover his total living costs and expenses because there were three breadwinners living in the household, including two of his brothers who also contributed to such costs.

${ }^{89}$ Cordesman et al., Afghan National Security Forces, 142; Hafvenstein, 'Afghanistan's Opium Strategy Alternatives', 125.

${ }^{90}$ It is important to note that this finding is not representative for the entire Nangarhar province.

${ }^{91}$ This patrolman has nine family members living in rented accommodation and earns 9,000 AFN per month for 15,000 AFN monthly total expenses but it is affordable due to the presence of three breadwinners within the household.

${ }^{92}$ The patrolman lives in rented accommodation consisting of four rooms with nine family members. He earns 12,500 AFN per month and pays 15,000 AFN for monthly living costs. ${ }^{93}$ The patrolman earns 11,500 AFN per month for 11 family members in rented accommodation consisting of five rooms with total monthly expenses and living costs amounting to $15,000 \mathrm{AFN}$.

${ }^{94}$ Both of these scenarios provide qualitative insights into the problems, faced by lower ranked police, of low pay and being posted in an away province due to random assignment.

${ }^{95}$ Goodhand and Hakimi, Counterinsurgency, Local Militias, and Statebuilding, 42.

${ }^{96}$ Wilder, Cops or Robbers?, 52.

${ }^{97}$ Goodhand, 'Poppy, Politics, and State Building', 63-64.

${ }^{98}$ Interview Advisor for the HOOAC, Kabul, 4 June 2010.

\section{References}

Alikuzai, Hamid Wahed, 2013. A Concise History of Afghanistan in 25 Volumes. Vol. 1 Trafford Publishing, Bloomington, IN. 
Axe, David, 2007. 'For Urban Afghans, Corruption Tops List of Everyday Annoyances'. World Politics Review, 21 June.

Azami, Sharif, 2009. 'The Need for Security Sector Reform in Afghanistan to Curb Corruption'. Corruption, Peace \& Conflict Monitor, 4 November.

Barakat, Sultan, Antonio Giustozzi, Christopher Langton, Michael Murphy, Mark Sedra and Arne Strand, 2008. A Strategic Conflict Assessment of Afghanistan. The University of York Recovery and Development Consortium, York.

Bayley, David and Robert M. Perito, 2011. Police Corruption: What Past Scandals Teach about Current Challenges. USIP Special Report, no. 294. USIP, Washington, DC.

Belay, Tekabe A., 2010. Building on Early Gains in Afghanistan's Health, Nutrition, and Population Sector: Challenges and Opinions. World Bank, Washington, DC.

Brummet, John, 2010. US Reconstruction Efforts in Afghanistan Would Benefit from a Finalised Comprehensive US Anti-Corruption Strategy. Office of the Special Inspector General for Afghanistan Reconstruction, Arlington, VA.

Carter, Stephen and Kate Clark, 2010. No Shortcut to Stability: Justice, Politics and Insurgency in Afghanistan. Chatham House, London.

Checchia, Mark, 2012. 'Corruption and the Afghan Security Forces'. In Corruption and AntiCorruption Issues in Afghanistan, ed. Civil-Military Fusion Centre. North Atlantic Treaty Organisation, Norfolk, VA, 36-42.

Chêne, Marie, 2008. Overview of Corruption in Pakistan. Transparency International, Berlin. Cliffe, Sarah and Nigel Roberts, 2011. World Development Report 2011: Conflict, Security, and Development. World Bank, Washington, DC.

Cordesman, Anthony H., Adam Mausner and David Kasten, 2009. Winning in Afghanistan: Creating Effective Afghan Security Forces. Centre for Strategic and International Studies (CSIS), Washington, DC. 
Cordesman, Anthony H., Adam Mausner and Jason Lemieux, 2010. Afghan National Security Forces: What It Will Take to Implement the ISAF Strategy. CSIS, Washington, DC. Emadi, Hafizullah, 2005. Culture and Customs of Afghanistan. Greenwood Press, Westport, CT.

Engelhardt, Tom, 2011. The United States of Fear. Haymarket Books, Chicago, IL. Felbab-Brown, Vanda, 2013. Aspiration and Ambivalence: Strategies and Realities of Counterinsurgency and Statebuilding in Afghanistan. Brookings Institution, Washington, DC.

Ghafoori, Abdul R., Laurent Zessler and Makoto Matsuda, 2012. 'Milestone in the History of Statistics in Afghanistan'. United Nations Population Fund Afghanistan, Kabul, 30 May.

Giustozzi, Antonio, 2008. 'Shadow Ownership and SSR in Afghanistan'. In Local Ownership and Security Sector Reform, ed. Timothy Donais. LIT Verlag, Zürich, 215-231.

Giustozzi, Antonio and Mohammad Isaqzadeh, 2011. Afghanistan's Paramilitary Policing in Context: The Risks of Expediency. Afghanistan Analysts Network, Kabul.

Giustozzi, Antonio and Mohammad Isaqzadeh, 2013. Policing Afghanistan: The Politics of the Lame Leviathan. Hurst, London.

Goodhand, Jonathan, 2008. 'Poppy, Politics, and State Building'. In Afghanistan: Transition under Threat, eds. Geoffrey Hayes and Mark Sedra. Wilfrid Laurier University Press, Waterloo, ON, 51-86.

Goodhand, Jonathan and Aziz Hakimi, 2014. Counterinsurgency, Local Militias, and Statebuilding in Afghanistan. USIP, Washington, DC.

Goodson, Larry P., 2001. Afghanistan's Endless War: State Failure, Regional Politics, and the Rise of the Taliban. University of Washington Press, Seattle, WA. 
Gupta, Akhil, 1995. 'Blurred Boundaries: The Discourse of Corruption, the Culture of Politics, and the Imagined State'. American Ethnologist 22(2), 375-402.

Hafvenstein, Joel, 2011. 'Afghanistan's Opium Strategy Alternatives-A Moment for Masterful Inactivity?'. In The Rule of Law in Afghanistan: Missing in Inaction, ed. Whit Mason. Cambridge University Press, Cambridge, 123-146.

Hughes, Michelle, 2011. The Afghan National Police in 2015 and Beyond. USIP Special Report, no. 346. USIP, Washington, DC.

Integrity Watch Afghanistan (IWA), 2010. Afghan Perceptions and Experiences of Corruption: A National Survey. IWA, Kabul.

Lansford, Tom, 2012. 9/11 and the Wars in Afghanistan and Iraq: A Chronology and Reference Guide. ABC-CLIO, LLC, Santa Barbara, CA.

Larivé, Maxime H.A., 2012. 'From Speeches to Actions: EU Involvement in the War in Afghanistan through the EUPOL Afghanistan Mission'. European Security 21(2), $185-201$.

Leonard, Barry, 2008. United States Plan for Sustaining the Afghanistan National Security Forces. Report to Congress in accordance with the 2008 National Defence Authorisation Act (Section 1231, Public Law 110-181).

Murray, Tonita, 2007. 'Police-Building in Afghanistan: A Case Study of Civil Security Reform'. International Peacekeeping 14(1), 108-126.

Nathan, Joanna, 2009. 'Reading the Taliban'. In Decoding the New Taliban: Insights from the Afghan Field, ed. Antonio Giustozzi. Hurst, New York, 23-42.

Nojumi, Neamatollah, Dyan E. Mazurana and Elizabeth Stites, 2004. Afghanistan's Systems of Justice: Formal, Traditional, and Customary. Feinstein International Famine Centre, Youth and Community Program, Tufts University, Medford, MA. 
Olivier de Sardan, Jean-Pierre, 1999. 'A Moral Economy of Corruption in Africa?'. Journal of Modern African Studies 37(1), 25-52.

Pape, Robert A. and James K. Feldman, 2010. Cutting the Fuse: The Explosion of Global Suicide Terrorism and How to Stop It. University of Chicago Press, Chicago, IL. Peters, Gretchen, 2009. How Opium Profits the Taliban. Vol. 31. USIP, Washington, DC. Planty, Donald J. and Robert M. Perito, 2013. Police Transition in Afghanistan. United States Institute of Peace Special Report, no. 322. USIP, Washington, DC.

Pothier, Fabrice, 2009. Opium in Afghanistan: A Reality Check. London School of Economics and Political Science (LSE) International Affairs Diplomacy Strategy Working Paper. LSE, London.

Royal United Services Institute for Defence and Security Studies, 2010. Reforming the Afghan National Police. RUSI, Washington, DC.

Ruud, Arild Engelsen, 1998. Corruption as Everyday Practice. Rules and Rule-Bending in Local Indian Society. SUM Working Paper, no. 4. Centre for Development and the Environment, Oslo.

Sedra, Mark, 2008. 'Small Arms and Security Sector Reform'. In Afghanistan, Arms and Conflict: Armed Groups, Disarmament and Security in a Post-war Society, eds. Mark Sedra and Michael Vinay Bhatia. Routledge, Oxon, 158-180.

Spilsbury, Richard, 2012. Discover Afghanistan. Rosen, New York.

Tomsen, Peter, 2011. The Wars of Afghanistan: Messianic Terrorism, Tribal Conflicts, and the Failures of Great Powers. Perseus Books, New York.

United Nations Development Programme (UNDP), 2009. Police Perception Survey 2009: The Afghan Perspective. UNDP, Kabul.

United Nations Office on Drugs and Crime (UNODC), 2012. Corruption in Afghanistan: Recent Patterns and Trends-Summary Findings. UNODC, Vienna, December. 
Wilder, Andrew, 2007. Cops or Robbers? The Struggle to Reform the Afghan National Police. Afghanistan Research and Evaluation Unit, Kabul. 